\title{
Evaluation of antioxidant, antimutagenic, and lipid peroxidation inhibitory activities of selected fractions of Holarrhena floribunda (G. Don) leaves
}

\author{
Jelili A. Badmus ${ }^{1,4}$, Oyeronke A. Odunola2 ${ }^{2}$ Taofeek A. Yekeen ${ }^{3}$, Adedapo M. Gbadegesin², \\ John O. Fatoki ${ }^{4}$, Muyideen O. Godo ${ }^{4}$, Kayode S. Oyebanjo ${ }^{4}$, Donavon C. Hiss ${ }^{1 凶}$
}

${ }^{1}$ Molecular Oncology Laboratory, Department of Medical Biosciences, University of the Western Cape, South Africa; ${ }^{2}$ Cancer Research and Molecular Biology Laboratories, Department of Biochemistry, University of Ibadan, Nigeria; ${ }^{3}$ Department of Pure and Applied Biology and ${ }^{4}$ Department of Biochemistry, Ladoke Akintola University of Technology, Ogbomoso, Nigeria

Exposure to environmental pollutants often leads to an upsurge in the production of reactive oxygen species (ROS). ROS oxidize cellular fatty acids to produce lipid peroxyl radicals, subsequently transformed into lipid peroxides, which decrease membrane fluidity and increase the activity of various enzymes implicated in degenerative diseases and cancer formation. Edible plants that contain exogenous compounds like curcumeroid, $\beta$-carotene, turmeric, and so on, protect the aerobic cells from oxidation of free radicals. This study thus evaluates antioxidant and antimutagenic activities of ethyl acetate, aqueous and methanolic fractions of Holarrhena floribunda leaves. Inhibitory activities of the ethyl acetate fraction on $\mathrm{Fe}^{2+}$-induced lipid peroxidation in hen egg yolk; rat liver and brain tissues were also evaluated. The Allium cepa root assay was used to evaluate antimutagenic activity. Results showed that the ethyl acetate scavenged $\mathrm{DPPH}, \mathrm{OH}$, and $\mathrm{O}_{2}^{-}$much stronger than other fractions, as evidenced by its lowest respective $I C_{50}$ values. All the fractions displayed antimutagenic activities against cyclophosphamide-induced chromosomal aberrations. Likewise, all the fractions induced a reduction in mitotic index, a hallmark of cytotoxicity in the root meristem of Allium cepa. The decrease in mitotic index was most profound for the ethyl acetate fraction, which also demonstrated a significant lipid peroxidation inhibitory activity in the liver and brain homogenates, but not in egg yolk, compared with the ascorbic acid standard. In general, the results suggest that the ethyl acetate fraction might contain beneficial phytochemicals that should be explored as novel candidates for preclinical drug development.

Key words: Holarrhena floribunda, ethyl acetate, aqueous, methanol, fractions, aberrations

Received: 28 February, 2013; revised: 28 June, 2013; accepted: S24 July, 2013; available on-line: 01 August, 2013

\section{INTRODUCTION}

Free radicals generated during normal cellular metabolism are not lethal to cells that constitutively express antioxidant enzymes, which clear them from the system. However, exposure to environmental pollutants such as heavy metals and ultra violet light leads to an upsurge in reactive oxygen species (ROS) (Rao et al., 2001) production and inability of cells to cope with the accumulation. Therefore, cellular fatty acids are readily oxidized by ROS to produce lipid peroxyl radicals that are subsequently transformed into lipid peroxides in the form of malondialdehyde (Rao et al., 2001; Rice-Evans \& Burdon, 1993; Bachowski et al., 1997). Lipid peroxidation decreases membrane fluidity and exacerbates the activity of various enzymes implicated in degenerative diseases and cancer (Cerutti, 1991; Finkel \& Holbrook, 2000). ROS oxidizes deoxyribose sugar and base residues of DNA causing single strand breaks, which eventually lead to double strand breaks (Breen \& Murphy, 1995). Consequently, the inability of the DNA repair mechanisms to restore the breaks leads to the formation of chromosomal aberration.

Some exogenous compounds obtained from food and vegetables such as curcumeroid, $\beta$-carotene, turmeric, and so on, do effectively protect the aerobic cells from oxidation of free radicals (Aqil et al., 2006). These phytochemicals have revealed both antigenotoxic and significant antioxidant potential. Furthermore, many ailments that afflict humans such as aging, arthritis, coronary heart disease, Alzheimer's disease, cataract, and cancer are known to be ROS-mediated and can be neutralized by the use of antioxidants (Devasagayam et al., 2004). These have thus led to an intensive search for natural plant products with antioxidant properties. Holarrhena floribunda (HF) leaves have a history of folklore uses for several diseases including malaria and diabetes. It has been reported to contain saponins, tannins, and cardiac glycoside. Also, antioxidant activity against radicals like $\mathrm{OH}^{\circ}, \mathrm{DPPH}$, $\mathrm{NO}_{2}{ }_{2}$, and Lipid peroxidation inhibition of the methanolic leaf extract of HF, have been reported (Badmus et al., 2010).

The present study sought to evaluate antioxidant, antimutagenic, and lipid peroxidation inhibition of some fractions of HF leaves against ascorbic acid as standard.

\section{MATERIALS AND METHODS}

Chemicals. Trichloroacetic acid (TCA), ferrous sulphate $\left(\mathrm{FeSO}_{4}\right)$, thiobarbituric acid (TBA), sodium dodelcyl sulphate (SDS), folin-ciocalteus, glacial acetic acid,

e-mail: J.A. Badmus, jabadmus@gmail.com; Donavon C. Hiss: dhiss@uwc.ac.za

Abbreviations: HF, Holarrhena floribunda; DPPH, 1,1-diphenyl-2-picryl-hydrazyl; MI, Mitotic index; MH, Mitotic inhibition; VM, Vagrant metaphase; TAC, Total aberrant cell; Conc, Concentration; AB, Anaphase bridge; FOA, Frequency of aberration; FC, Fragmented chromosome. 
ascorbic acid, 1,1 diphenyl-2-picrylhydrazyl (DPPH), and Orcein salt were procured from Sigma Co (St. Louis, MO) USA. Cyclophosphamide was purchased from Candila Healthcare Limited, Germany. All other reagents used were of analytical grades.

Extraction procedure. The powdered leaves of HF $(1.5 \mathrm{~kg})$ were exhaustively extracted with 4.5 liters of $70 \%$ methanol. The methanolic filtrate was concentrated under reduced pressure to yield a methanolic extract. A fraction of this extract was suspended in distilled water and partitioned with $n$-hexane, chloroform, and ethyl acetate. Each fraction was concentrated under reduced pressure to yield their respective fractions. The methanolic, ethyl acetate, and aqueous fractions were used for the evaluations.

In-vitro Antioxidant assay. The DPPH scavenging potential was estimated as previously described (Mensor et al., 2001). One $\mathrm{ml}$ of a $0.3 \mathrm{mM}$ DPPH methanol solution was added to a $2.5 \mathrm{ml}$ solution of each fraction and allowed to react at room temperature in the dark for 30 min. The absorbance of the resulting mixture was measured at $517 \mathrm{~nm}$.

The hydroxyl radical scavenging ability of the fractions was evaluated as previously described (Halliwell et al., 1987). The reaction mixtures used contain ascorbic acid $(200 \mu \mathrm{M}), \mathrm{FeCl}_{3}(200 \mu \mathrm{M})$, EDTA $(200 \mu \mathrm{M}), \mathrm{H}_{2} \mathrm{O}_{2}$ $(20 \mathrm{mM})$, deoxyribose $(5 \mathrm{mM})$ with different concentrations of the fractions in $1 \mathrm{ml}$ of PBS $(20 \mathrm{mM}, \mathrm{pH} 7.4)$. The mixture was incubated at $37^{\circ} \mathrm{C}$ for $1 \mathrm{~h}$ and then 1 $\mathrm{ml}$ of $2.8 \%$ TCA (w/v in water) and $1 \mathrm{ml}$ of $0.8 \%$ TBA $(\mathrm{w} / \mathrm{v})$ were added. The mixture was heated in a boiling water bath for $15 \mathrm{~min}$. It was cooled and absorbance was measured at $532 \mathrm{~nm}$.

Table 1. DPPH scavenging ability of methanolic, aqueous, and ethyl acetate fractions of Holarrhena floribunda leaves and ascorbic acid.

\begin{tabular}{|c|c|c|c|c|}
\hline Sample & $\begin{array}{l}\text { Concentration } \\
(\mu \mathrm{g} / \mathrm{ml})\end{array}$ & $\%$ inhibition $(n=5)$ & Regression equation & $\mathrm{IC}_{50}(\mu \mathrm{g} / \mathrm{ml})$ \\
\hline \multirow[t]{5}{*}{ Methanolic } & 10 & $6.30 \pm 0.011$ & $Y=1.295 X-9.410$ & 45.90 \\
\hline & 20 & $9.90 \pm 0.026$ & $\left(r^{2}=0.9568\right)$ & \\
\hline & 30 & $34.30 \pm 0.011$ & & \\
\hline & 40 & $41.40 \pm 0.008$ & & \\
\hline & 50 & $55.30 \pm 0.014$ & & \\
\hline \multirow[t]{5}{*}{ Aqueous } & 50 & $51.20 \pm 0.005$ & $Y=0.0834 X+48.85$ & $15.00^{*}$ \\
\hline & 100 & $58.10 \pm 0.004$ & $\left(r^{2}=0.9403\right)$ & \\
\hline & 150 & $63.50 \pm 0.005$ & & \\
\hline & 200 & $65.80 \pm 0.005$ & & \\
\hline & 250 & $68.20 \pm 0.009$ & & \\
\hline \multirow[t]{5}{*}{ Ethyl acetate } & 5 & $51.10 \pm 0.007$ & $Y=0.0834 X+48.85$ & $3.60^{*}$ \\
\hline & 10 & $57.10 \pm 0.006$ & $\left(r^{2}=0.9987\right)$ & \\
\hline & 15 & $62.30 \pm 0.006$ & & \\
\hline & 20 & $67.20 \pm 0.013$ & & \\
\hline & 25 & $72.50 \pm 0.010$ & & \\
\hline \multirow[t]{5}{*}{ Ascorbic acid } & 5 & $54.20 \pm 0.007$ & $Y=0.8580 X+49.51$ & $0.57^{*}$ \\
\hline & 10 & $56.90 \pm 0.006$ & $\left(r^{2}=0.9850\right)$ & \\
\hline & 15 & $63.00 \pm 0.006$ & & \\
\hline & 20 & $67.40 \pm 0.013$ & & \\
\hline & 25 & $70.40 \pm 0.006$ & & \\
\hline
\end{tabular}

Data were expressed as means \pm S.D. of five parallel measurements. ${ }^{*} C_{50}$ was calculated from the regression equation.
Superoxide anion scavenging ability was assessed as previously described (Beauchamp \& Fridovich, 1971). The reaction mixture contained $50 \mathrm{mM}$ phosphate buffer (pH 7.6), $20 \mu \mathrm{g}$ riboflavin, $12 \mathrm{mM}$ EDTA, NBT $(0.1 \mathrm{mg} / 3 \mathrm{ml})$ added in that order. The reaction was initiated by illuminating the reaction mixture using fluorescent lamps $(20 \mathrm{~W})$ with different concentrations of fractions for $150 \mathrm{~s}$. The absorbance was measured at $590 \mathrm{~nm}$ immediately after illumination.

The absorbance of the entire assay was converted to percentage antioxidant activity (AA\%), using the formula;

$\mathrm{AA} \%=\left[\left(\mathrm{Abs}_{\text {blank }}-\mathrm{Abs}_{\text {sample }}\right) \times 100\right]$

Allium cepa assay. Healthy onion bulbs (Allium cepa L. $2 n=16)$ of similar size were purchased from Wazo market at Ogbomoso, Oyo state, Nigeria. The onions were sun dried for three weeks so as to reduce the moisture content and facilitate growth. The dried outer scales were carefully removed leaving the ring of primordial roots intact. These were used for bioassay according to the standard procedure. Ten onion bulbs were used for each fraction and controls. Tap water was used as negative control, cyclophosphamide as positive control, and ascorbic acid as a standard control. The base of each of the bulbs was suspended on the extract inside $100 \mathrm{ml}$ capacity beaker. Test extracts and control media were changed daily. The experiment was performed in the dark at $25 \pm 1{ }^{\circ} \mathrm{C}$. Five onion bulbs were harvested from each group after 48 $h$ of growth for microscopic evaluation. Onion root tips were prepared for microscopic evaluation as previously described (Akinboro \& Bakare, 2007; Lateef et al., 2007). A number of diving cells and chromosomal aberrations in 5000 cells per concentration were analyzed. Mitotic index (MI), mitotic inhibition $(\mathrm{MH})$ and frequency of aberrant cells (FOA) were calculated (Akinboro \& Bakare, 2007).

Mitotic index $(\mathrm{MI})=$ number of dividing cells in the treatment $\times 100$.

Total number of cells. Mitotic inhibition $(\mathrm{MH})=$ mitotic index of control - mitotic index of treatment $\times 100$.

Mitotic index of control. Frequency of aberrant cells (FOA) = number of aberrant cells in the treatment.

Total number of dividing cells in the treatment. Dose selection and experimental protocol. The dose of the fractions used for antimutagenic activity in the A. cepa assay was based on different concentrations $(1: 1,1: 10$, $1: 100$ and $1: 1000)$ of fractions tested on the growth of onion roots (results not presented here). The choice of 1:1000 concentration was based on the fact that at least no fractions of $\mathrm{HF}$ support less than $45 \%$ root growth.

Antimutagenic effects of fractions were evaluated by pregrowing the $A$. cepa in the medium containing the individual 
Table 2. Hydroxyl radical scavenging ability of methanolic, aqueous, and ethyl acetate fractions of Holarrhena floribunda leaves and ascorbic acid.

\begin{tabular}{|c|c|c|c|c|}
\hline Sample & $\begin{array}{l}\text { Concentration } \\
(\mu \mathrm{g} / \mathrm{ml})\end{array}$ & $\%$ inhibition $(n=5)$ & Regression equation & $\mathrm{IC}_{50}(\mu \mathrm{g} / \mathrm{ml})$ \\
\hline \multirow[t]{4}{*}{ Methanolic } & 400 & $45.30 \pm 0.007$ & $Y=0.0139 X+39.86$ & 700.0 \\
\hline & 500 & $47.50 \pm 0.002$ & $\left(r^{2}=0.9808\right)$ & \\
\hline & 600 & $48.80 \pm 0.002$ & & \\
\hline & 800 & $51.30 \pm 0.001$ & & \\
\hline \multirow[t]{5}{*}{ Aqueous } & 12.5 & $38.80 \pm 0.003$ & $Y=0.143 X+37.18$ & 90.1 \\
\hline & 25.0 & $40.60 \pm 0.003$ & $\left(r^{2}=0.9901\right)$ & \\
\hline & 50.0 & $44.50 \pm 0.006$ & & \\
\hline & 75.0 & $48.70 \pm 0.002$ & & \\
\hline & 100.0 & $50.90 \pm 0.003$ & & \\
\hline \multirow[t]{5}{*}{ Ethyl acetate } & 10 & $45.20 \pm 0.004$ & $Y=0.2058 X+43.4$ & 32.5 \\
\hline & 20 & $47.90 \pm 0.003$ & $\left(r^{2}=0.9694\right)$ & \\
\hline & 30 & $49.90 \pm 0.004$ & & \\
\hline & 50 & $52.50 \pm 0.002$ & & \\
\hline & 60 & $56.50 \pm 0.004$ & & \\
\hline \multirow[t]{5}{*}{ Quercetin } & 10 & $20.20 \pm 0.004$ & $Y=0.6320 X-9.680$ & 49.5 \\
\hline & 20 & $23.00 \pm 0.006$ & $\left(r^{2}=0.6618\right)$ & \\
\hline & 30 & $23.70 \pm 0.004$ & & \\
\hline & 40 & $26.00 \pm 0.003$ & & \\
\hline & 50 & $50.30 \pm 0.004$ & & \\
\hline
\end{tabular}

Data were expressed as means \pm S.D. of five parallel measurements.

Table 3. Superoxide anion scavenging ability of methanolic, aqueous, and ethyl acetate fractions of Holarrhena floribunda leaves and ascorbic acid.

\begin{tabular}{|c|c|c|c|c|}
\hline Sample & $\begin{array}{l}\text { Concentration } \\
(\mu \mathrm{g} / \mathrm{ml})\end{array}$ & $\%$ inhibition $(n=5)$ & Regression equation & $\mathrm{IC}_{50}(\mu \mathrm{g} / \mathrm{ml})$ \\
\hline \multirow[t]{5}{*}{ Methanolic } & 3.3 & $25.80 \pm 0.007$ & $Y=3.345 X+16.45$ & 10.05 \\
\hline & 6.7 & $42.70 \pm 0.012$ & $\left(r^{2}=0.9594\right)$ & \\
\hline & 10.0 & $50.20 \pm 0.010$ & & \\
\hline & 13.3 & $55.70 \pm 0.012$ & & \\
\hline & 16.7 & $75.10 \pm 0.007$ & & \\
\hline \multirow[t]{5}{*}{ Aqueous } & 3.3 & $28.50 \pm 0.012$ & $Y=4.372 X+22.38$ & 6.35 \\
\hline & 6.7 & $57.70 \pm 0.010$ & $\left(r^{2}=0.9111\right)$ & \\
\hline & 10.0 & $72.40 \pm 0.006$ & & \\
\hline & 13.3 & $84.10 \pm 0.003$ & & \\
\hline & 16.7 & $88.30 \pm 0.001$ & & \\
\hline \multirow[t]{5}{*}{ Ethyl acetate } & 1.33 & $04.50 \pm 0.004$ & $Y=14.08 X-13.07$ & 4.60 \\
\hline & 2.67 & $22.50 \pm 0.017$ & $\left(r^{2}=0.9787\right)$ & \\
\hline & 4.00 & $45.50 \pm 0.015$ & & \\
\hline & 5.33 & $68.20 \pm 0.013$ & & \\
\hline & 6.67 & $75.60 \pm 0.003$ & & \\
\hline \multirow[t]{5}{*}{ Ascorbic acid } & 0.67 & $11.30 \pm 0.005$ & $Y=26.61 X-7.78$ & 2.17 \\
\hline & 1.33 & $22.60 \pm 0.023$ & $\left(r^{2}=0.9794\right)$ & \\
\hline & 2.00 & $48.50 \pm 0.031$ & & \\
\hline & 2.67 & $67.40 \pm 0.017$ & & \\
\hline & 3.30 & $76.60 \pm 0.003$ & & \\
\hline
\end{tabular}

Data were expressed as means \pm S.D. of five parallel measurements. fraction and ascorbic acid (control) for $24 \mathrm{~h}$ and then transferred to cyclophosphamide medium for another 24 $\mathrm{h}$ before analysis (pre-treatment). This procedure was reversed for the second group, where $A$. cepa were first grown in cyclophosphamide medium for $24 \mathrm{~h}$ before being transferred to growth media of different fractions (post-treatment).

Inhibition of lipid peroxidation. Inhibitions of lipid peroxidation in the egg of hen, liver and brain homogenates of rat were determined using a modified (Ohkawa et al., 1979) thiobarbituric acidreactive species (TBARS) assay as previously described (Ruberto et al., 2000). Egg homogenate $(0.5 \mathrm{ml}, 10 \%$ in distilled water, $\mathrm{v} / \mathrm{v}$ ) and $0.1 \mathrm{ml}$ of each fraction were mixed separately in a test tube and the volume was made up to 1 $\mathrm{ml}$, by adding distilled water. Finally, $0.05 \mathrm{ml} \mathrm{FeSO}_{4}(0.07$ $\mathrm{M})$ was added to the above mixture and incubated for 30 min, to induce lipid peroxidation. Thereafter, $1.5 \mathrm{ml}$ of $20 \%$ acetic acid and $1.5 \mathrm{ml}$ of $0.8 \%$ TBA (w/v) in $1.1 \%$ sodium dodecyl sulfate (SDS) and $0.05 \mathrm{ml} \mathrm{20 \%}$ TCA was added, vortexed and then heated in a boiling water bath for $60 \mathrm{~min}$. After cooling, 5.0 $\mathrm{ml}$ of butanol was added to each tube and centrifuged at $3000 \mathrm{rpm}$ for $10 \mathrm{~min}$. The absorbance of the organic upper layer was measured at $532 \mathrm{~nm}$. Also, $10 \%$ of liver and brain homogenates obtained from rat were also used in place of egg homogenate for the evaluation of lipid peroxidation.

Statistical analysis. Data were expressed as mean \pm standard deviation (SD) from five different experiments. Results were analyzed statistically using one-way analysis of variance (ANOVA) followed by Dunnett's test. The regression curve analysis was used to calculate $\mathrm{IC}_{50}$ using Graph Pad Prism version 5.02 statistical software. $\mathrm{IC}_{50}$ value is a concentration of extract required to scavenge $50 \%$ free radical and is inversely proportional to the activity of the extract. 


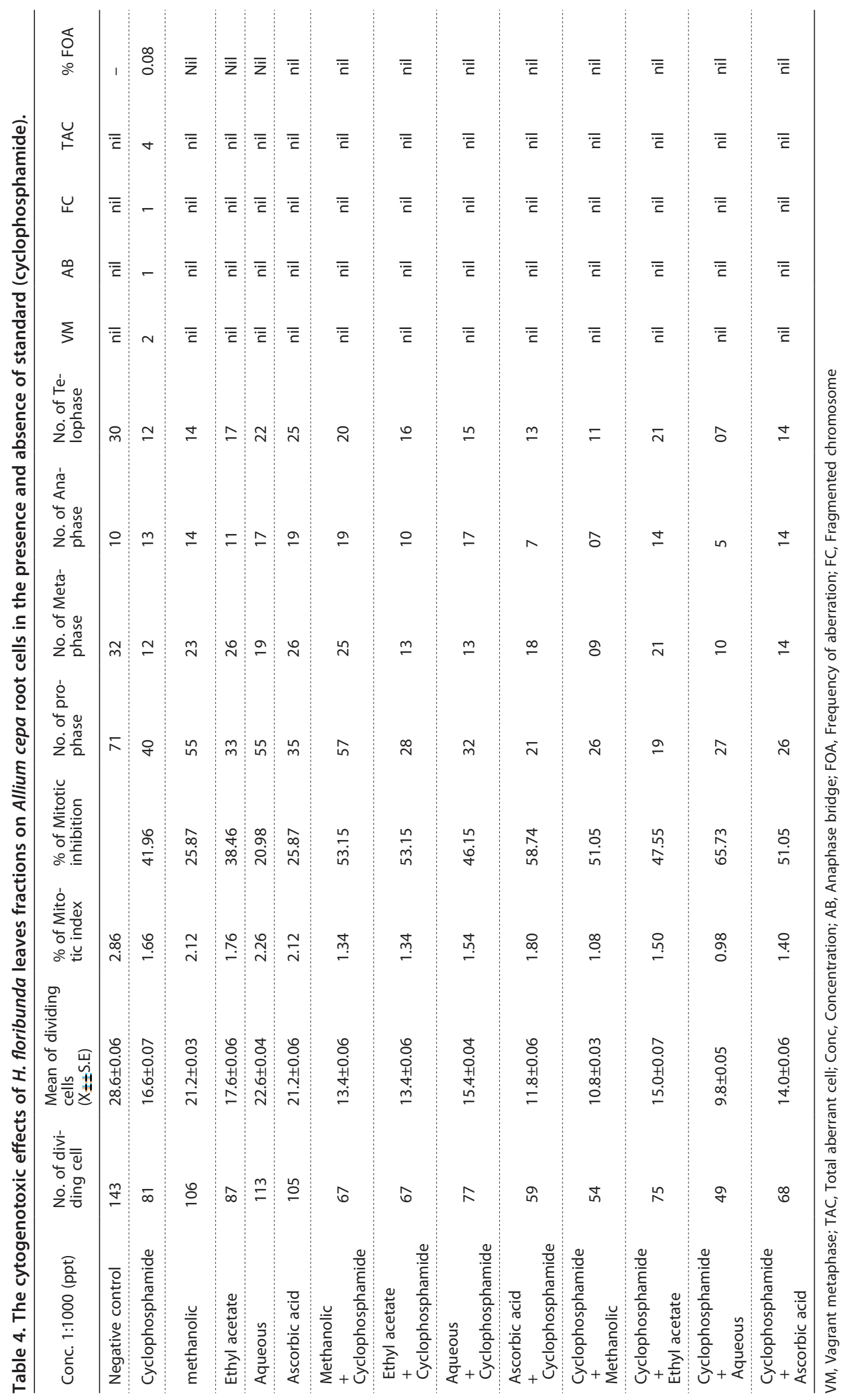




\section{RESULTS}

\section{DPPH radical scavenging}

$\mathrm{IC}_{50}$ values of the fractions and ascorbic acid were calculated using the regression equation as stated in Table 1. Ethyl acetate fraction showed significant DPPH scavenging activity with $\mathrm{IC}_{50}$ of $3.60 \mu \mathrm{g} / \mathrm{ml}$ with a regression equation of $\mathrm{Y}=0.0834 \mathrm{X}+48.85$ and $\mathrm{r}^{2}=0.9987$. This was followed by the aqueous fraction $\left(\mathrm{IC}_{50}=15.00 \mu \mathrm{g} / \mathrm{ml}, \mathrm{Y}=0,0834 \mathrm{X}+48.85\right.$ and $\mathrm{r}^{2}=0.9403$ ), methanolic fraction $\left(\mathrm{IC}_{50}=45.90 \mu \mathrm{g} / \mathrm{ml}\right.$, $\mathrm{Y}=1.295 \mathrm{X}-9.410$ and $\left.\mathrm{r}^{2}=0.9568\right)$. Ascorbic acid used as standard showed significant scavenging of DPPH with $\mathrm{IC}_{50}=0.57 \mu \mathrm{g} / \mathrm{ml}$.

\section{Hydroxyl radical scavenging}

All the fractions showed concentration dependent hydroxyl radical scavenging activities compared with the standard quercetin. Methanolic fraction scavenged hydroxyl radical with $\mathrm{IC}_{50}$ of $700.0 \mu \mathrm{g} / \mathrm{ml}$, scavenging regression equation of $\mathrm{Y}=0.0139 \mathrm{X}+39.86$ and $\mathrm{r}^{2}=0.9808$. Aqueous fraction had $\mathrm{IC}_{50}$ of $90.1 \mu \mathrm{g} /$ $\mathrm{ml}$ with a regression equation $\mathrm{Y}=0.143 \mathrm{X}+37.18$ and $\mathrm{r}^{2}=0.9901$. Ethyl acetate showed $\mathrm{IC}_{50}$ of $32.5 \mu \mathrm{g} /$ $\mathrm{ml}$ with a regression equation of $\mathrm{Y}=0.2058 \mathrm{X}+43.40$ and $\mathrm{r}^{2}=0.9694$. Quercetin had $\mathrm{IC}_{50}$ of $49.5 \mu \mathrm{g} / \mathrm{ml}$ with a regression equation of $\mathrm{Y}=0.6320 \mathrm{X}-9.680$ and $\mathrm{r}^{2}=0.6618$. This result shows that ethyl acetate had highest scavenging potential against hydroxyl radical compared with other fractions and standard quercetin (Table 2).

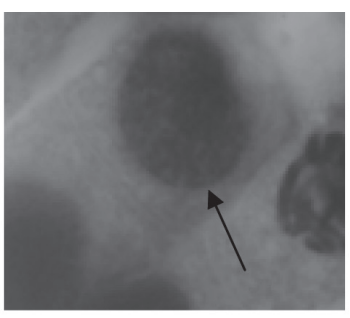

a: Interphone

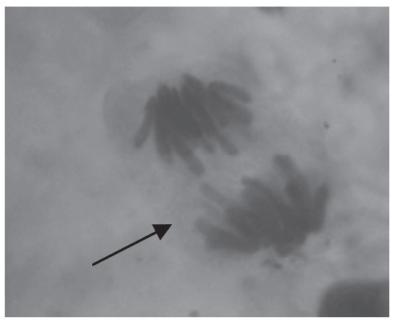

d: Anaphase

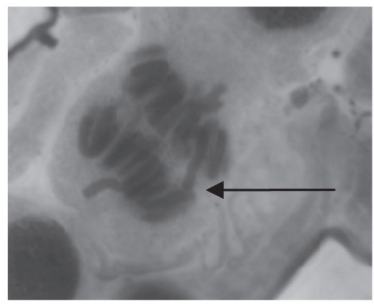

g: Anaphase bridge

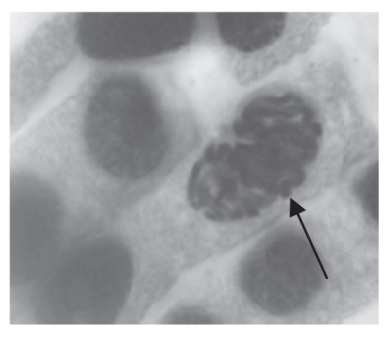

b: Prophase

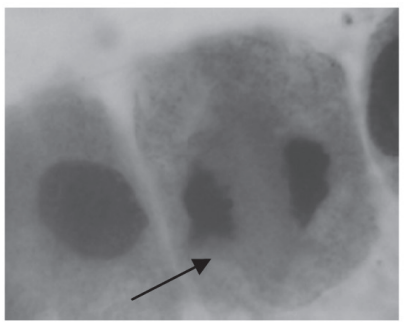

e: Telophase

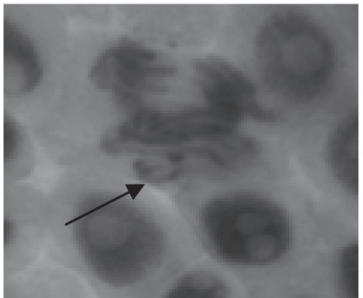

h: Fragmented chromosome
Figure 1a-h. Normal stages of cell division and the observed chromosomal aberrations in cylophosphamide and $\mathrm{H}$. floribunda treated Allium cepa. 
duction effects were observed in the methanolic and ethyl acetate fractions. Chromosomal aberrations were observed in the cyclophosphamide treated Allium cepa roots, whereas no aberrant cell was observed in the HF fractions, ascorbic acid and at both the post and pretreatment combination of fractions and cyclophosphamide.

\section{Inhibition of lipid peroxidation}

Ethyl acetate fraction had higher lipid peroxidation inhibition in the egg yolk with $\mathrm{IC}_{50}$ of $41.9 \mu \mathrm{g} / \mathrm{ml}$, regression equation $\mathrm{Y}=1.006 \mathrm{X}+7.959$ with $\mathrm{r}^{2}=0.9156$ compared with standard ascorbic acid with $\mathrm{IC}_{50}$ of 45.9 $\mu \mathrm{g} / \mathrm{ml}$, regression equation $\mathrm{Y}=0.7322 \mathrm{X}+11.90$ with $r^{2}=0.9222$ (Table 5).

Table 5. Effects of the ethyl acetate fraction and ascorbic acid on the $\mathrm{Fe}^{2+}$-induced lipid peroxidation in hen's egg yolk, rat brain and liver

\begin{tabular}{|c|c|c|c|c|}
\hline Sample & $\begin{array}{l}\text { Concentration } \\
(\mu \mathrm{g} / \mathrm{ml})\end{array}$ & $\%$ inhibition $(n=5)$ & Regression equation & $\mathrm{IC}_{50}(\mu \mathrm{g} / \mathrm{ml})$ \\
\hline \multirow{6}{*}{$\begin{array}{l}\text { Egg yolk } \\
\text { Ethyl acetate }\end{array}$} & & & & \\
\hline & 09.50 & $11.70 \pm 0.007$ & $Y=1.006 X+7.959$ & 41.9 \\
\hline & 19.00 & $33.10 \pm 0.013$ & $\left(r^{2}=0.9156\right)$ & \\
\hline & 28.57 & $39.30 \pm 0.012$ & & \\
\hline & 38.00 & $46.10 \pm 0.007$ & & \\
\hline & 47.62 & $53.10 \pm 0.019$ & & \\
\hline \multirow[t]{5}{*}{ Ascorbic acid } & 09.50 & $20.60 \pm 0.012$ & $Y=0.7322 X+11.90$ & 45.9 \\
\hline & 19.00 & $26.10 \pm 0.003$ & $\left(r^{2}=0.9222\right)$ & \\
\hline & 28.57 & $31.10 \pm 0.014$ & & \\
\hline & 38.00 & $35.40 \pm 0.004$ & & \\
\hline & 47.62 & $50.80 \pm 0.015$ & & \\
\hline \multirow{6}{*}{$\begin{array}{l}\text { Brain } \\
\text { Ethyl acetate }\end{array}$} & & & & \\
\hline & 09.50 & $28.00 \pm 0.010$ & $Y=1.825 X+8.658$ & 22.6 \\
\hline & 14.29 & $32.00 \pm 0.006$ & $\left(r^{2}=0.9838\right)$ & \\
\hline & 19.00 & $43.00 \pm 0.011$ & & \\
\hline & 23.81 & $53.00 \pm 0.012$ & & \\
\hline & 28.57 & $61.00 \pm 0.008$ & & \\
\hline \multirow[t]{5}{*}{ Ascorbic acid } & 09.50 & $13.00 \pm 0.022$ & $Y=1.428 X+1.649$ & 33.9 \\
\hline & 19.00 & $30.00 \pm 0.030$ & $\left(r^{2}=0.9916\right)$ & \\
\hline & 28.57 & $45.00 \pm 0.025$ & & \\
\hline & 38.00 & $56.00 \pm 0.006$ & & \\
\hline & 47.62 & $68.00 \pm 0.012$ & & \\
\hline \multirow{6}{*}{$\begin{array}{l}\text { Liver } \\
\text { Ethyl acetate }\end{array}$} & & & & \\
\hline & 09.50 & $22.00 \pm 0.016$ & $Y=2.224 X-0.537$ & 22.7 \\
\hline & 14.29 & $31.00 \pm 0.019$ & $\left(r^{2}=0.9903\right)$ & \\
\hline & 19.00 & $40.00 \pm 0.021$ & & \\
\hline & 23.81 & $51.00 \pm 0.021$ & & \\
\hline & 28.57 & $65.00 \pm 0.007$ & & \\
\hline \multirow[t]{5}{*}{ Ascorbic acid } & 09.50 & $07.40 \pm 0.012$ & $Y=1.4863 X-10.64$ & 40.8 \\
\hline & 19.00 & $12.90 \pm 0.030$ & $\left(r^{2}=0.9516\right)$ & \\
\hline & 28.57 & $37.50 \pm 0.040$ & & \\
\hline & 38.00 & $41.80 \pm 0.052$ & & \\
\hline & 47.62 & $65.90 \pm 0.009$ & & \\
\hline
\end{tabular}

Data were expressed as means \pm S.D. of five parallel measurements.
Table 5 shows the results of inhibition of lipid peroxidation in brain homogenate. Ethyl acetate had $\mathrm{IC}_{50}$ of $22.6 \mu \mathrm{g} / \mathrm{ml}$, regression equation $\mathrm{Y}=1.825 \mathrm{X}+8.658$ and $\mathrm{r}^{2}=0.9838$ compared with ascorbic acid which had $\mathrm{IC}_{50}$ of $33.9 \mu \mathrm{g} / \mathrm{ml}$, regression equation $\mathrm{Y}=1.428 \mathrm{X}+1.649$ and $\mathrm{r}^{2}=0.9916$. Ethyl acetate showed significant inhibition of lipid peroxidation in brain compared with ascorbic acid.

Inhibition of $\mathrm{Fe}^{2+}$-induced lipid peroxidation in liver homogenate was significantly stronger than ascorbic acid. Ethyl acetate inhibited the lipid peroxidation with $\mathrm{IC}_{50}$ of $22.7 \mu \mathrm{g} / \mathrm{ml}$, regression equation $\mathrm{Y}=2.224 \mathrm{X}-0.537$ with $\mathrm{r}^{2}=0.9903$ compared with ascorbic acid with $\mathrm{IC}_{50}$ of $40.8 \mu \mathrm{g} / \mathrm{ml}$, regression equation $\mathrm{Y}=1.4863 \mathrm{X}-10.64$ and $\mathrm{r}^{2}=0.9516$ as presented in Table 5 .

\section{DISCUSSION}

The importance of searching for alternative plant products against a number of diseases associated with ROS continues to be popular because of limited toxicity associated with it as against synthetic products. Epidemiological studies have revealed that diets rich in fruit and vegetables correlate with a reduced risk of chronic diseases such as cardiovascular disease and some forms of cancer (Liu et al., 2000; Gheldof et al., 2003). However, a volume of work has been done to unravel some inherent benefits of some natural products. Consequently, this has led to the isolation of bioactive agents for clinical candidates. Furthermore, a large gap is still needed to be filled because there are a lot of potentially beneficial plants that are yet to be studied.

The antioxidant potential of methanolic extract of Holarrhena floribunda has been previously reported (Badmus et al., 2010). In the continuous effort to evaluate potential medicinal values of the leaves of $\mathrm{HF}$, the present research was conducted to investigate antioxidant and antimutagenic activities of methanolic, ethyl acetate, and aqueous extracts of HF. Lipid peroxidation inhibition of ethyl acetate fraction in the rat liver, brain, and hen's egg yolk homogenates were also assessed.

DPPH is a stable, free radical that reacts with a compound that has an H-donating ability. Its reduction to diphenylpicrylhydrazine after the reaction changes the colour from dark-purple to yellow and it is detected at wavelength of 517 $\mathrm{nm}$. DPPH method is easy, ac- 
curate, and reproducible, and it is comparable to other free radical scavenging systems (Gil et al., 2000). All the fractions show dose dependent DPPH scavenging ability. This result shows that the ethyl acetate fraction can release $\mathrm{H}$ atom to stabilize the DPPH radical better than other fractions tested except Ascorbic acid.

Hydroxyl radical is the main reactive oxygen species involved in the induction of lipid peroxidation in the biological membrane by abstracting hydrogen atom from unsaturated fatty acids (Aruoma et al., 1987). This radical also has the ability to initiate carcinogenesis, mutagenesis, and cytotoxicity (Esmaeili \& Sonboli, 2010). This result shows that ethyl acetate prevents the Fenton reaction generated hydroxyl radical from oxidizing ribose sugar better than other tested fractions and the standard. The implication of this result is that ethyl acetate can protect the cell membrane from the oxidizing potential of hydroxyl radical better than any other tested fractions. Superoxide anion is known to play roles in initiating other reactive oxygen species such as $\mathrm{H}_{2} \mathrm{O}_{2}, \mathrm{OH}^{-}$, and $\mathrm{O}^{2-}$ (Pietta, 2000). Its reaction with nitric oxide forms peroxylnitrite anion $\left(\mathrm{ONOO}^{-}\right)$, which leads to an increase in the nitric oxide toxicity (Huie \& Padmaja, 1993). All the fractions show significant scavenging activity against riboflavin/NBT/illumination induced $\mathrm{SO}_{2}^{-}$. Ethyl acetate had the highest activity with $\mathrm{IC}_{50}$ value of $4.47 \mu \mathrm{g} / \mathrm{ml}$, followed by aqueous $(6.13 \mu \mathrm{g} / \mathrm{ml})$ and methanolic extract $(9.83 \mu \mathrm{g} / \mathrm{ml})$. However, this implies that the fractions have the ability to protect the cell against various deleterious effects of $\mathrm{SO}_{2}^{-}$.

Allium cepa test is a fast, inexpensive, and sensitive method. It has been validated in international collaborative studies under the United Nations Environmental Program (UNEP), World Health Organization (WHO), and US Environmental Protection Agency (USEPA) as an efficient test for genetic monitoring of environmental Pollutant (Grant, 1999). Mitotic index (MI) is a parameter used to estimate the frequency of cell division in Allium cepa root (Turkoglu, 2008). Reduction of MI was observed in cyclophosphamide, Holarrbena floribunda fractions, and Vitamin C separately treated roots. Reductions of MI in ethyl acetate treated roots were higher when compared to other fractions and very close to that of cyclophosphamide treated roots. Also, ethyl acetate showed the highest reduction of MI in pre-treatment of the fractions before cyclophosphamide treated Allium cepa roots. The lowest reduction of MI was observed in post-treatment of ethyl acetate fraction when compared to other fractions and ascorbic acid. Reduction of mitotic index has been attributed to the inhibition of DNA synthesis and blocking of G2 phase of the cell cycle, thereby preventing the cell from entering mitosis (Van't Hof, 1968; Sudhakar et al., 2001). The reduction of MI value lower than individual control may suggest the level of cytotoxicity that substance inflicts on meristematic cells (Akinboro \& Bakare, 2007). From the present results, the ethyl acetate fraction is more cytotoxic than any other fraction and ascorbic acid. This could be attributed to the possible presence of phytochemicals such as alkaloids, tannins, and cardiac glycoside. These compounds have been shown to initiate cytotoxicity, antimutagenic, and antioxidant activities (Talib \& Mahasneh, 2010; Park et al., 2009).

Improper or un-repair oxidation of DNA deoxyribose sugar and a nitrogenous base of ROS lead to double strand break, which contributes to chromosomal aberrations (Breen \& Murphy, 1995; Maluszynska \& Juchimiuk, 2005). The results presented in Table 4 and Figure 1 (fh) showed that cyclophosphamide induced vagrant meta- phase, anaphase bridge, and fragmented chromosomes. Induction of vagrant has been shown to lead to the formation of daughter cells with unequal sized or irregularly shaped nuclei at interphase because of unequal numbers of chromosomes in the daughter cells (El-Ghamery et al., 2003). Formation of bridges also could be attributed to chromosome breaks, stickiness and breakage/ reunion of broken ends (Yildiz et al., 2009). All these aberrations were absent in all the fractions, either treated alone or in combination with cyclophosphamide (Post or pre) treated $A$. cepa roots. This shows that all the fractions have the ability to protect $A$. cepa meristemic cells from cyclophosphamide induced mutagenesis.

Polyunsaturated lipid contents of the biological membrane are susceptible to oxidative reaction of free radicals, which lead to lipid peroxidation. Products of lipid peroxidation such as malondialdeyde (MDA), 4-hydroxyl 2 -nonenal, and some other alkanes react with cell macromolecules to form adducts with significant irreversible effects on cellular functions and biochemistry (Onyema et al., 2003; Tuma \& Casey, 2003). Consequently, the formation of adduct leads to membrane permeability, oxidative nucleic acid damage, and eventually to mutation and cancer (Brawn \& Fridovich, 1981; Halliwell \& Gutteridge, 1984). However, on the basis of antioxidant and antimutagenic activities the most active fraction was tested for lipid peroxidation inhibition. Lipid peroxidation was induced in three media of different lipid contents and characteristics (liver, brain and egg yolk) using ferric chloride. Inhibitions of lipid peroxidation in liver and brain homogenates by ethyl acetate were found to be significantly stronger when compared to ascorbic acid. Inhibition of lipid peroxidation in egg yolk by ethyl acetate was not significantly different when compared with ascorbic acid. These results showed that most of the number of reported phytochemicals of $H$. floribunda such as tannins, saponins, alkaloid, cardiac glycosides, and phenolic compound (Badmus et al., 2010) could be higher in ethyl acetate fraction.

\section{CONCLUSION}

The present investigation shows that Holarrbena floribunda leaves are rich in phytochemicals that have antioxidant, antimutagenic and lipid peroxidation inhibition activities. However, the activities exhibited by the ethyl acetate fraction indicate that it contains more of these phytochemicals. Further research is required to elucidate the phytochemical contents of this fraction as well as its cytotoxic and antimutagenic properties.

\section{REFERENCE}

Akinboro A, Bakare AA (2007) Cytotoxic and genotoxic effects of aqueous extracts of five medicinal plants on Allium cepa Linn. J Ethnopharmacol 112: 470-475.

Aqil F, Ahmed I, Mehmood Z (2006) Antioxidant and free radical scavenging properties of twelve traditionally used indian medicinal plants. Turk J Biol 30: 177-183.

Aruoma OI, Wasil M, Halliwell B, Hoey BM, Butler J (1987) The scavenging of oxidants by sulphasalazine and its metabolites. A possible contribution to their anti-inflammatory effects? Biochem Pharmacol 36: 3739-3742.

Bachowski S, Kolaja KL, Xu Y, Ketcham CA, Stevenson DE, Walborg EF, Jr., Klaunig JE (1997) Role of oxidative stress in the mechanism of dieldrin's hepatotoxicity. Ann Clin Lab Sci 27: 196-209.

Badmus JA, Odunola OA, Obuotor EM, Oyedapo OO (2010) Phytochemicals and in vitro antioxidant potentials of defatted methanolic extract of Holarrhena floribunda leaves. Afr J Biotechnol 9: 340-346.

Beauchamp C, Fridovich I (1971) Superoxide dismutase: improved assays and an assay applicable to acrylamide gels. Anal Biochem: 44: 276-287. 
Brawn K, Fridovich I (1981) DNA strand scission by enzymically generated oxygen radicals. Arch Biochem Biophys 206: 414-419.

Breen AP, Murphy JA (1995) Reactions of oxyl radicals with DNA. Free Radic Biol Med 18: 1033-1077.

Cerutti PA (1991) Oxidant stress and carcinogenesis. Eur J Clin Invest 21: $1-5$.

Devasagayam TP, Tilak JC, Boloor KK, Sane KS, Ghaskadbi SS, Lele RD (2004) Free radicals and antioxidants in human health: current status and future prospects. I Assoc Physicians India 52: 794-804.

El-Ghamery AA, El-Kholy MA, Abou El-Yousser MA (2003). Evaluation of cytological effects of $\mathrm{Zn}^{2+}$ in relation to germination and root growth of Nigella sativa L. and Triticum aestivum L. Mutat Res-Gen Tox En 537: 29-41.

Esmaeili MA, Sonboli A, (2010) Antioxidant, free radical scavenging activities of Salvia brachyantha and its protective effect against oxidative cardiac cell injury. Food Chem Toxicol 48: 846-853.

Finkel T, Holbrook NJ (2000) Oxidants, oxidative stress and the biology of ageing. Nature 408: 239-247.

Gheldof N, Wang XH, Engeseth NJ (2003) Buckwheat honey increases serum antioxidant capacity in humans. J Agr Food Chem 51: 1500-1505.

Gil MI, Tomas-Barberan FA, Hess-Pierce B, Holcroft DM, Kader AA (2000) Antioxidant activity of pomegranate juice and its relationship with phenolic composition and processing. J Agr Food Chem 48: 4581-4589.

Grant WF (1999) Higher plant assays for the detection of chromosomal aberrations and gene mutations-a brief historical background on their use for screening and monitoring environmental chemicals. Mutat Res 426: 107-112.

Halliwell B, Gutteridge JM (1984) Lipid peroxidation, oxygen radicals, cell damage, and antioxidant therapy. Lancet 1: 1396-1397.

Halliwell B, Gutteridge JM, Aruoma OI (1987) The deoxyribose method: a simple "test-tube" assay for determination of rate constants for reactions of hydroxyl radicals. Anal Biochemi 165: 215-219.

Huie RE, Padmaja S (1993) The reaction of no with superoxide. Free Radic Res Commun 18: 195-199.

Lateef A, Yekeen TA, Ufoma P (2007) Bacteriology and Genotoxicity of some Pharmacaeutical wastewater in Nigeria. Int J Environ Heal 4: 551-562.

Liu S, Manson JE, Lee IM, Cole SR, Hennekens CH, Willett WC, Buring JE (2000) Fruit and vegetable intake and risk of cardiovascular disease: the Women's Health Study. Am Jo Clin Nutr 72: 922-928.

Maluszynska J, Juchimiuk J (2005) Plant genotoxicity: a molecular cytogenetic approach in plant bioassays. Arb Hig Rada Toksikol 56: $177-184$.
Mensor LL, Menezes FS, Leitao GG, Reis AS, dos Santos TC, Coube CS, Leitao SG, (2001) Screening of Brazilian plant extracts for antioxidant activity by the use of DPPH free radical method. Phytother Res 15: 127-130.

Ohkawa H, Ohishi N, Yagi K (1979). Assay for lipid peroxides in animal tissues by thiobarbituric acid reaction. Anal Biochem 95: 351-358.

Onyema OO, Farombi EO, Emerole GO, Ukoha AI, Onyeze GO (2006) Effect of vitamin $\mathrm{E}$ on monosodium glutamate induced hepatotoxicity and oxidative stress in rats. Indian J Biochem Biophys 43: $20-24$.

Park YS, Towantakavanit K, Kowalska T, Jung ST, Ham KS, Heo BG, Cho JY, Yun JG, Kim HJ, Gorinstein S (2009) Bioactive compounds and antioxidant and antiproliferative activities of Korean white lotus cultivars. J Med Food 12: 1057-1064.

Pietta PG (2000) Flavonoids as antioxidants. J Nat Prod 63: 1035-1042.

Rao CV, Hirose Y, Indranie C, Reddy BS (2001) Modulation of experimental colon tumorigenesis by types and amounts of dietary fatty acids. Cancer Res 61: 1927-1933.

Rice-Evans C, Burdon R (1993) Free radical-lipid interactions and their pathological consequences. Prog Lipid Res 32: 71-110.

Ruberto G, Baratta MT, Deans SG, Dorman HJ (2000) Antioxidant and antimicrobial activity of Foeniculum vulgare and Crithmum maritimum essential oils. Planta Med 66: 687-693.

Sudhakar R, Gowda KNN, Venu G (2001) Mitotic abnormalities induced by silk dyeing industry effluents in the cells of Allium cepa. Cytologia 66: 235-239.

Talib WH, Mahasneh AM (2010) Antimicrobial, cytotoxicity and phytochemical screening of Jordanian plants used in traditional medicine. Molecules 15: 1811-1824.

Tuma DJ, Casey CA (2003) Dangerous byproducts of alcohol breakdown - focus on adducts. Alcohol Res Health 27: 285-290.

Turkoglu S (2008) Evaluation of genotoxic effects of sodium propionate, calcium propionate and potassium propionate on the root meristem cells of Allium cepa. Food Chem Toxicol 46: 2035-2041.

Van't Hof J (1968) The action of IAA and kinetin on the mitotic cycle of proliferative and stationary phase excised root meristems. Exp Cell Res 51: 167-176.

Yildiz M, Cigerci IH, Konuk M, Fidan AF, Terzi H (2009) Determination of genotoxic effects of copper sulphate and cobalt chloride in Allium cepa root cells by chromosome aberration and comet assays. Chemosphere 75: 934-938. 